\title{
Simplifying aerosol size distributions modes simultaneously detected at four monitoring sites during SAPUSS
}

\author{
M. Brines ${ }^{1,2}$, M. Dall'Osto ${ }^{1, *}$, D.C.S. Beddows ${ }^{3}$, R. M. Harrison ${ }^{3,4}$, and X. Querol ${ }^{1}$ \\ ${ }^{1}$ Institute of Environmental Assessment and Water Research (IDÆA) Consejo Superior de Investigaciones Científicas (CSIC), \\ C/ Jordi Girona 18-26, 08034 Barcelona, Spain \\ ${ }^{2}$ Department of Astronomy and Meteorology, Faculty of Physics, University of Barcelona, C/ Martí i Franquès 1, 08028 \\ Barcelona, Spain \\ ${ }^{3}$ National Centre for Atmospheric Science Division of Environmental Health \& Risk Management School of Geography, \\ Earth \& Environmental Sciences, University of Birmingham, Edgbaston, Birmingham, B15 2TT, UK \\ ${ }^{4}$ Department of Environmental Sciences/Center of Excellence in Environmental Studies, King Abdulaziz University, Jeddah, \\ 21589, Saudi Arabia \\ * now at: Institute of Marine Sciences (ICM) Consejo Superior de Investigaciones Científicas (CSIC), Pg Marítim de la \\ Barceloneta 37-49, 08003 Barcelona, Spain
}

Received: 19 September 2013 - Published in Atmos. Chem. Phys. Discuss.: 22 October 2013

Revised: 27 January 2014 - Accepted: 3 February 2014 - Published: 25 March 2014

\begin{abstract}
The analysis of aerosol size distributions is a useful tool for understanding the sources and the processes influencing particle number concentrations $(\mathrm{N})$ in urban areas. Hence, during the one-month SAPUSS campaign (Solving Aerosol Problems by Using Synergistic Strategies, EU Marie Curie Action) in autumn 2010 in Barcelona (Spain), four SMPSs (Scanning Mobility Particle Sizer) were simultaneously deployed at four monitoring sites: a road side $\left(\mathrm{RS}_{\text {site }}\right)$, an urban background site located in the city (UB site), an urban background site located in the nearby hills of the city (Torre Collserola, $\mathrm{TC}_{\text {site }}$ ) and a regional background site located about $50 \mathrm{~km}$ from the Barcelona urban areas $\left(\mathrm{RB}_{\text {site }}\right)$. The spatial distribution of sites allows study of the aerosol temporal variability as well as the spatial distribution, progressively moving away from urban aerosol sources. In order to interpret the data sets collected, a $k$-means cluster analysis was performed on the combined SMPS data sets. This resulted in nine clusters describing all aerosol size distributions from the four sites. In summary there were three main categories (with three clusters in each category): "Traffic" (Traffic 1, "T $\mathrm{T}_{\text {clus_1 }}$ " $-8 \%$; Traffic 2, "T $\mathrm{T}_{\text {clus_2" }}-13 \%$; and

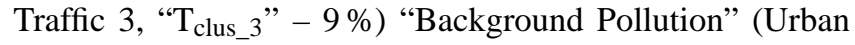
Background 1, "UB $\mathrm{UB}_{\text {clus_1 }}$ " $-21 \%$; Regional Background 1, "RB clus_1 $_{1}-15 \%$; and Regional Background 2, "RB clus_2" $_{\text {- }}$ $18 \%$ ) and "Special Cases" (Nucleation, "NU clus" - $5 \%$; Regional Nitrate, "NIT $T_{\text {clus }}$ " $6 \%$; and Mix, "MIX clus" $-5 \%$ ).
\end{abstract}

As expected, the frequency of traffic clusters $\left(\mathrm{T}_{\text {clus_1-3 }}\right)$ followed the order $\mathrm{RS}_{\text {site }}, \mathrm{UB}_{\text {site }}, \mathrm{TC}_{\text {site }}$, and $\mathrm{RB}_{\text {site. }}$. These showed typical traffic modes mainly distributed at $20-40 \mathrm{~nm}$. The urban background sites $\left(\mathrm{UB}_{\text {site }}\right.$ and $\left.\mathrm{TC}_{\text {site }}\right)$ reflected also as expected urban background number concentrations (average values, $\mathrm{N}=1.0 \times 10^{4} \mathrm{~cm}^{-3}$ and $\mathrm{N}=5.5 \times 10^{3} \mathrm{~cm}^{-3}$, respectively, relative to $1.3 \times 10^{4} \mathrm{~cm}^{-3}$ seen at $\left.\mathrm{RS}_{\text {site }}\right)$. The cluster describing the urban background pollution $\left(\mathrm{UB}_{\text {clus_1 }}\right)$ could be used to monitor the sea breeze circulation towards the regional background study area. Overall, the $\mathrm{RB}_{\text {site }}$ was mainly characterised by two different regional background aerosol size distributions: whilst both exhibited low $\mathrm{N}\left(2.7 \times 10^{3}\right.$ for $\mathrm{RB}_{\text {clus } \_1}$ and $2.2 \times 10^{3} \mathrm{~cm}^{-3}$ for $\mathrm{RB}_{\text {clus_2}}$ ), $\mathrm{RB}_{\text {clus_1 } 1}$ had average $\mathrm{PM}_{10}$ concentrations higher than $\mathrm{RB}_{\text {clus } \_2}\left(27\right.$ vs. $23 \mu \mathrm{g} \mathrm{m}^{-3}$ ). As regards the minor aerosol size distribution clusters, the "Nucleation" cluster was observed during daytime, whilst the "Regional Nitrate" was mainly seen at night. The ninth cluster ("Mix") was the least well defined and likely composed of a number of aerosol sources.

When correlating averaged values of $\mathrm{N}, \mathrm{NO}_{2}$ and $\mathrm{PM}$ (particulate mass) for each $k$-means cluster, a linear correlation between $\mathrm{N}$ and $\mathrm{NO}_{2}$ with values progressively increasing from the regional site $\mathrm{RB}_{\text {site }}$ to the road site $\mathrm{RS}_{\text {site }}$ was found. This points to vehicular traffic as the main source of both $\mathrm{N}$ and $\mathrm{NO}_{2}$. By contrast, such an association does not exist 
for the case of the nucleation cluster, where the highest $\mathrm{N}$ is found with low $\mathrm{NO}_{2}$ and $\mathrm{PM}$.

Finally, the clustering technique allowed study of the impact of meteorological parameters on the traffic $\mathrm{N}$ emissions. This study confirms the shrinking of freshly emitted particles (by about $20 \%$ within $1 \mathrm{~km}$ in less than $10 \mathrm{~min}$; Dall'Osto et al., 2011a) as particles are transported from the traffic hot spots towards urban background environments. Additionally, for a given well-defined aerosol size distribution ( $\left.\mathrm{T}_{\text {clus_2 } 2}\right)$ associated with primary aerosol emissions from road traffic we found that $\mathrm{N}_{5-15 \mathrm{~nm}}$ concentrations can vary up to a factor of eight.

Within our measurement range of SMPSs $\left(\mathrm{N}_{15}-228 \mathrm{~nm}\right)$ and Condensation Particle Counters (CPCs, $\mathrm{N}_{>5} \mathrm{~nm}$ ), we found that ultrafine particles within the range $5-15 \mathrm{~nm}$ in urban areas are the most dynamic, being a complex ensemble of primary evaporating traffic particles, traffic tailpipe new particle formation and non-traffic new particle formation.

\section{Introduction}

Air pollution is a major social concern, especially in urban agglomerations where anthropogenic emissions are an important source of ultrafine particles (UFPs, diameter < $100 \mathrm{~nm}$ ). These may have a natural or an anthropogenic origin and may be emitted to the atmosphere directly or formed as a result of different atmospheric processes. UFPs are very abundant in number but have little aerosol mass (Harrison and Yin, 2000). Because of their small size they are suggested to be more toxic than coarser particles per unit mass (Davidson et al., 2005; Seaton et al., 1995). Recent epidemiological studies have shown that particle number concentration is directly related to cardiovascular mortality (Atkinson et al., 2010). Additionally, aerosols influence the Earth's radiative balance, either directly or indirectly, through their effect on the albedo and lifetimes of clouds (IPCC, 2007).

Within urban environments, road traffic is found to be the main source through tailpipe emissions (Pey et al., 2009; Kumar et al., 2011). Vehicle exhausts emit both primary particles and gaseous pollutants. Semi-volatile organic compounds can be rapidly converted into aerosols by secondary processes (Charron and Harrison, 2003). However, the variability of particle levels in urban ambient air is not only dependent on the number of vehicles but is also influenced by the geographical, climatological and the meteorological features of the study area (Birmili et al., 2000; Hussein et al., 2006; Olivares et al., 2007).

A large gradient of $\mathrm{N}$ is found within urban areas of Europe. In northern European countries $\mathrm{N}$ is usually correlated with primary traffic markers during all seasons (Hussein at al., 2004), whereas in the southern European countries the scenario is far more complex. Indeed, Reche et al. (2011) showed that the high insolation registered in
Mediterranean cities enhances nucleation events, thus increasing N. It should be kept in mind that the Mediterranean climate is also encountered in other cities worldwide like Los Angeles and Brisbane (Hudda et al., 2010; Cheung et al., 2011). The present work was carried out in Barcelona, a major city located in the NE part of Spain in the western Mediterranean basin (WMB).

The objective of this study was to identify the atmospheric processes and sources affecting the size-selected aerosol concentrations simultaneously detected at four different monitoring sites in the Barcelona area. The unique approach herein presented derives from the spatial distribution of the monitoring sites used, both at horizontal and vertical levels within the city of Barcelona. Four SMPS (Scanning Mobility Particle Sizer) instruments at four different monitoring sites were deployed during the Marie Curie EU Action SAPUSS (Solving Aerosol Problems by Using Synergistic Strategies), allowing us to obtain a large data set characterised by high time resolution (five minutes) and high aerosol size resolution ( 34 bins in the size range of $15-228 \mathrm{~nm}$ ).

In order to reduce the complexity of such a large data set, statistical cluster analysis was used to group similarly sized distributions into the same category, while keeping the number of different clusters to a minimum (Beddows et al., 2009). By applying this analysis to particle size distribution measurements taken simultaneously at different monitoring sites, the aerosol variability and transport within such study sites (Beddows et al., 2009; Dall'Osto et al., 2011b) can be studied.

It should be remembered that the SMPS clustering data herein presented correspond only to the SAPUSS intensive field study of one month and are thus influenced by the season (autumn) and the year (2010). A study on the spatial and temporal variability of $\mathrm{N}_{>5} \mathrm{~nm}$ during the SAPUSS study can be found in this ACP SAPUSS special issue (Dall'Osto et al., 2013a). Previous studies on the same study area have focused on yearly data (2004) and can be found elsewhere (Pey et al., 2008, 2009; for relative clustering analysis see Dall'Osto et al., 2012). Additionally, during this study some important conclusions are drawn on the effect of meteorological parameters on the emissions of primary traffic particles as well as on the correlation of $\mathrm{N}_{>5} \mathrm{~nm}$ with some air quality parameters $\left(\mathrm{NO}_{\mathrm{x}}, \mathrm{PM}_{\mathrm{x}}\right)$.

\section{Methodology}

\subsection{Location}

Barcelona is a coastal city located in the northeast of Spain in the WMB. It is confined by the coastal range of Collserola to the north, the Mediterranean Sea to the southeast and two river valleys, the Besòs River to the northeast and the Llobregat River to the west. The city has 1.7 million inhabitants, or around 4 million counting the metropolitan area. The major 
PM pollution source is traffic as the city has a high vehicle density (6100 cars km${ }^{-2}$; Amato et al., 2009). The city has a number of complex meteorological scenarios, ranging from stagnant anticyclonic conditions to African dust outbreaks, as well as almost daily sea breeze dynamics. A detailed characterisation of the western Mediterranean basin climatological features can be found in Millán et al. (2000) and in the SAPUSS overview paper (Dall'Osto et al., 2013b). Within the Barcelona region, the SAPUSS measurement campaign took place from 20 September to 20 October 2010. Out of the six monitoring sites, for the purpose of this study we consider the four which were equipped with an SMPS (Dall'Osto et al., 2013b):

- The Road Site $\left(\mathrm{RS}_{\text {site }}\right)$ was located in the car park of Escola Tècnica d'Enginyeria Industrial on Urgell Street, a street canyon with four vehicle lanes (one direction) and two cycling lanes in both directions. This street is representative of the urban traffic related to commercial activity, and during the SAPUSS campaign the approximate vehicle intensity was 17000 cars day $^{-1}$.

- The Urban Background monitoring station $\left(\mathrm{UB}_{\text {site }}\right)$ was located in a park of a residential area at the northwest of the city centre, about $80 \mathrm{~m}$ a.s.l. It was also close to the busy Diagonal Avenue (9 lane road) that crosses the city from east to west and is primarily used by commuters. It reflects the rush hour traffic peaks and has a traffic volume of about 62000 cars day $^{-1}$.

- Torre Collserola sampling site $\left(\mathrm{TC}_{\text {site }}\right)$ is found at the Fabra observatory, an astronomical observatory at $415 \mathrm{~m}$ altitude above sea level, and located about $450 \mathrm{~m}$ (900 m road distance) from the tower Collserola site (tower site; Dall'Osto et al., 2013b). It characterises the suburban environment of the city and is affected by the boundary layer daily cycle and the seamountain breeze circulation.

- The Regional Background site $\left(\mathrm{RB}_{\text {site }}\right)$ is located in the Montseny natural park, about $50 \mathrm{~km}$ to the northnortheast of Barcelona. This measuring station is part of the ACTRIS network (Aerosols, Clouds, and Trace gases Research InfraStructure Network; formerly EUSAAR) under the abbreviation MSY. It is regularly affected by a diurnal mountain breeze as it is located at 720 m.a.s.l.

It is important to stress that this spatial layout allows us to study point source emissions at the $\mathrm{RS}_{\text {site }}$ being transported to the urban background sites $\left(\mathrm{UB}_{\text {site }}\right.$ and $\left.\mathrm{TC}_{\text {site }}\right)$ and later on to the $\mathrm{RB}_{\text {site }}$ (see overview paper in this special issue, Dall'Osto et al., 2013b).

\subsection{Measurements}

\subsubsection{Size-segregated aerosol concentrations}

Four different SMPS instruments with 5 min time resolution were simultaneously deployed at the four sites. Although the use of aerosol drier is advisable (Colbeck et al., 2014; Swietlicki at al., 2008) in future studies, unfortunately it was not possible to use during this campaign. The instrument specifications at each site are as follows.

- $\mathrm{RS}_{\text {site }}$ : Differential Mobility Analyser (DMA) TSI 3080 and a TSI CPC 3010 (11-322 nm for a total of $511 \mathrm{~h})$.

- UB ${ }_{\text {site }}$ : DMA TSI 3080 coupled with a TSI CPC 3775 (15-228 $\mathrm{nm}$ for $424 \mathrm{~h}$ ).

- TC site: DMA TSI 3034 with an in-built CPC (10$470 \mathrm{~nm}$ for $585 \mathrm{~h}$ ).

- $\mathrm{RB}_{\text {site }}$ : the SMPS deployed was a EUSAAR IfT Model coupled with a TSI CPC 3772 (10-470 nm for $486 \mathrm{~h}$ ).

The size ranges and the number of size bins were different for each SMPS ( $\mathrm{RS}_{\text {site }}$ : 48 bins; $\mathrm{UB}_{\text {site }}: 39$ bins; $\mathrm{TC}_{\text {site }}$ : 54 bins; $\mathrm{RB}_{\text {site }}: 54$ bins). In order to harmonise the data, they were averaged at hourly resolution to the size ranges of the $\mathrm{UB}_{\text {site }}$, in order to obtain a homogeneous data set that could allow an intercomparison between all sites. This resulted in a data matrix of particle size distributions ranging from 15 to $228 \mathrm{~nm}$ (39 bins) that contained $2006 \mathrm{~h}$ of measurements distributed across the four sites. All SMPS instruments were calibrated and intercompared beforehand, resulting in excellent agreement as shown in Dall'Osto et al. (2013b). They also provided an excellent temporal overlap (85\%). Additionally, total particle number concentrations were obtained by the use of additional CPCs at the three city sites $\left(\mathrm{RS}_{\text {site }}\right.$, $\mathrm{UB}_{\text {site }}$ and $\mathrm{TC}_{\text {site }}$ ). At the $\mathrm{RS}_{\text {site }}$ and $\mathrm{TC}_{\text {site }}$ the $\mathrm{CPC}$ deployed was a buthanol-based TSI Model 3022A with a $50 \%$ cutpoint at $7 \mathrm{~nm}$, while at the $\mathrm{UB}_{\text {site }}$ and $\mathrm{RB}_{\text {site }}$ the CPC deployed was a water-based TSI Model 3785 with a lower cutpoint at $5 \mathrm{~nm}$. The CPCs were intercompared before and after the campaign, giving excellent overlap, with uncertainties around 5\% both times (Dall'Osto et al., 2013b). Biswas et al. (2005) intercompared both water-based and buthanolbased instruments and concluded that they showed a similar response, always within the uncertainty of the manufacturer $( \pm 10 \%)$.

\subsubsection{Other measurements}

Meteorological parameters (temperature, relative humidity $(\mathrm{RH})$, wind components, solar radiation and atmospheric pressure) were measured at the four sites described above $\left(\mathrm{RS}_{\text {site }}, \mathrm{UB}_{\text {site }}, \mathrm{TC}_{\text {site }}, \mathrm{RB}_{\text {site }}\right)$. Gaseous pollutants such as $\mathrm{NO}, \mathrm{NO}_{2}, \mathrm{O}_{3}, \mathrm{SO}_{2}$, and $\mathrm{CO}$ were also measured using the 
Table 1. Overall occurrence (\%) of each cluster, classified into different scenarios as well as at each site $\left(\mathrm{RS}_{\text {site }}, \mathrm{UB}_{\text {site }}, \mathrm{TC}_{\text {site }}\right.$ and $\left.\mathrm{RB}_{\text {site }}\right)$.

\begin{tabular}{|c|c|c|c|c|c|c|}
\hline Type & Time $(\%)$ & $\begin{array}{l}k \text {-means } \\
\text { cluster }\end{array}$ & $\begin{array}{l}\text { Road Site } \\
\left(\mathrm{RS}_{\text {site }}\right)\end{array}$ & $\begin{array}{l}\text { Urban Background } \\
\left(\mathrm{UB}_{\text {site }}\right)\end{array}$ & $\begin{array}{l}\text { Torre Collserola } \\
\left(\mathrm{TC}_{\text {site }}\right)\end{array}$ & $\begin{array}{l}\text { Regional } \\
\text { Background } \\
\left(\mathrm{RB}_{\text {site }}\right)\end{array}$ \\
\hline \multirow{3}{*}{ Traffic: $30 \%$} & $8 \%$ & Traffic $1\left(\mathrm{~T}_{\text {clus_1 }}\right)$ & $24 \%$ & $1 \%$ & $5 \%$ & $2 \%$ \\
\hline & $13 \%$ & Traffic 2 ( $\left.\mathrm{T}_{\text {clus_2}}\right)$ & $47 \%$ & $1 \%$ & $3 \%$ & $1 \%$ \\
\hline & $9 \%$ & Traffic 3 ( $\mathrm{T}_{\text {clus_3 }}$ ) & $1 \%$ & $22 \%$ & $14 \%$ & $0 \%$ \\
\hline \multirow{3}{*}{ Background Pollution: $54 \%$} & $21 \%$ & Urban Back. 1 (UB clus_1 $_{\text {) }}$ & $15 \%$ & $28 \%$ & $26 \%$ & $14 \%$ \\
\hline & $15 \%$ & Reg. Back. 1 (RB (lus_1 $\left._{\text {( }}\right)$ & $0 \%$ & $19 \%$ & $18 \%$ & $22 \%$ \\
\hline & $18 \%$ & Reg. Back. 2 (RB clus_2 $\left._{2}\right)$ & $3 \%$ & $17 \%$ & $15 \%$ & $39 \%$ \\
\hline \multirow{3}{*}{ Special case: $16 \%$} & $5 \%$ & Nucleation $\left(\mathrm{NU}_{\text {clus }}\right)$ & $1 \%$ & $11 \%$ & $6 \%$ & $1 \%$ \\
\hline & $6 \%$ & Reg. Nitrate (NIT clus) & $2 \%$ & $1 \%$ & $7 \%$ & $14 \%$ \\
\hline & $5 \%$ & $\operatorname{Mix}\left(\mathrm{MIX}_{\text {clus }}\right)$ & $7 \%$ & $0 \%$ & $6 \%$ & $7 \%$ \\
\hline
\end{tabular}

standard techniques described by Dall'Osto et al. (2013b). Levels of black carbon (BC) were measured with a MultiAngle Absorption Photometer (MAAP). Particulate matter fractions $\mathrm{PM}_{10}, \mathrm{PM}_{2.5}$ and $\mathrm{PM}_{1}$ were continuously measured with optical dust monitors (Grimm Labortechnik Model 1107).

\subsection{Data analysis}

Given the amount of data to be interpreted and the complexity of the study (involving four monitoring sites) a statistical analytical method was applied to the SMPS data set using $k$-means cluster analysis, in which the particle size distributions were generalised by cluster types (characteristic of an emission or formation process) which facilitated an understanding of the temporal and spatial trends of the size distributions. It classifies spectra with the highest degree of similarity into the same category or cluster, therefore reducing the number of spectra to analyse (Beddows et al., 2009). The cluster analysis was performed on the hourly averaged data of all four sites together (39 size bins and $2006 \mathrm{~h}$ ), which allowed study of the transport and spatial evolution of aerosols in the urban environment of Barcelona and its region.

\section{Results}

\section{$3.1 k$-means clustering analysis}

The $k$-means clustering analysis performed on the SAPUSS SMPS data resulted in nine clusters. Cluster validation indices were used to choose the optimum number of spectra to divide the data as described elsewhere (Beddows et al., 2009; Dall'Osto et al., 2011b). This is solely a statistical optimisation, not accounting for the scientific context in which the data were collected, based on the shape of the spectra. To reduce the possibility that any clusters combined spectra from two different sources or processes, a higher optimum cluster number (in the range 10-20) was selected in the initial analysis. Having studied the cluster within a scientific context, common clusters were recombined (Dall'Osto et al., 2011b) and for our data set this procedure resulted in a ninecluster solution. The results herein presented summarise all the particle size distributions acquired during SAPUSS at the four monitoring sites (Fig. 1). Please note that the size distributions reported in Fig. 1 are extrapolated to the largest size depending on the site, given the good agreement shown between the harmonised (resulting from the $k$-means clustering analysis) and the raw spectra. The nine clusters show a very different frequency among the four different monitoring sites (Table 1). This is expected due to the different aerosol sources affecting each site. Such a complex scenario can be broadly summarised in three main aerosol categories:

- Three of the clusters are associated with "Traffic" ( $\mathrm{T}_{\text {clus_1 }}, \mathrm{T}_{\text {clus_2 }}$ and $\mathrm{T}_{\text {clus_3 }}$ ) and prevailed during $30 \%$ of all measured hours. Within the Traffic category, the differences between clusters are due to the proximity to the traffic source and to the atmospheric processes affecting aerosols after emission, such as evaporation (Dall'Osto et al., 2011a; Harrison et al., 2012). As expected, the $\mathrm{RS}_{\text {site }}$ is the most affected by traffic emission as it is located close to traffic sources (Table 1). Indeed, $\mathrm{T}_{\text {clus_1 }}$ and $\mathrm{T}_{\text {clus_2 }}$ clusters are almost exclusive to the $\mathrm{RS}_{\text {site }}$ and account for 24 and $47 \%$ of the hours measured at this site, respectively (Table 1). In contrast, $\mathrm{T}_{\text {clus_3 }}$ is associated with the urban background stations of $\mathrm{UB}_{\text {site }}(22 \%)$ and $\mathrm{TC}_{\text {site }}(14 \%)$, which are more distant from traffic sources. As expected, the regional $\mathrm{RB}_{\text {site }}$ is not characterised by primary traffic size distributions.

- Three clusters referred to the "Background Pollution" category (UB $\mathrm{UB}_{\text {clus_1 }}$ - Urban Background 1; RB $\mathrm{R}_{\text {clus_1 }}$ - Regional Background 1; and $\mathrm{RB}_{\text {clus_2 }}$ - Regional Background 2) characterised the overall aerosol population for $54 \%$ of the sampling time. They were predominantly found at the background sites of $\mathrm{UB}_{\text {site }}$, $\mathrm{TC}_{\text {site }}$ and $\mathrm{RB}_{\text {site }}$. Cluster $\mathrm{UB}_{\text {clus_1 }}$ was found at all 


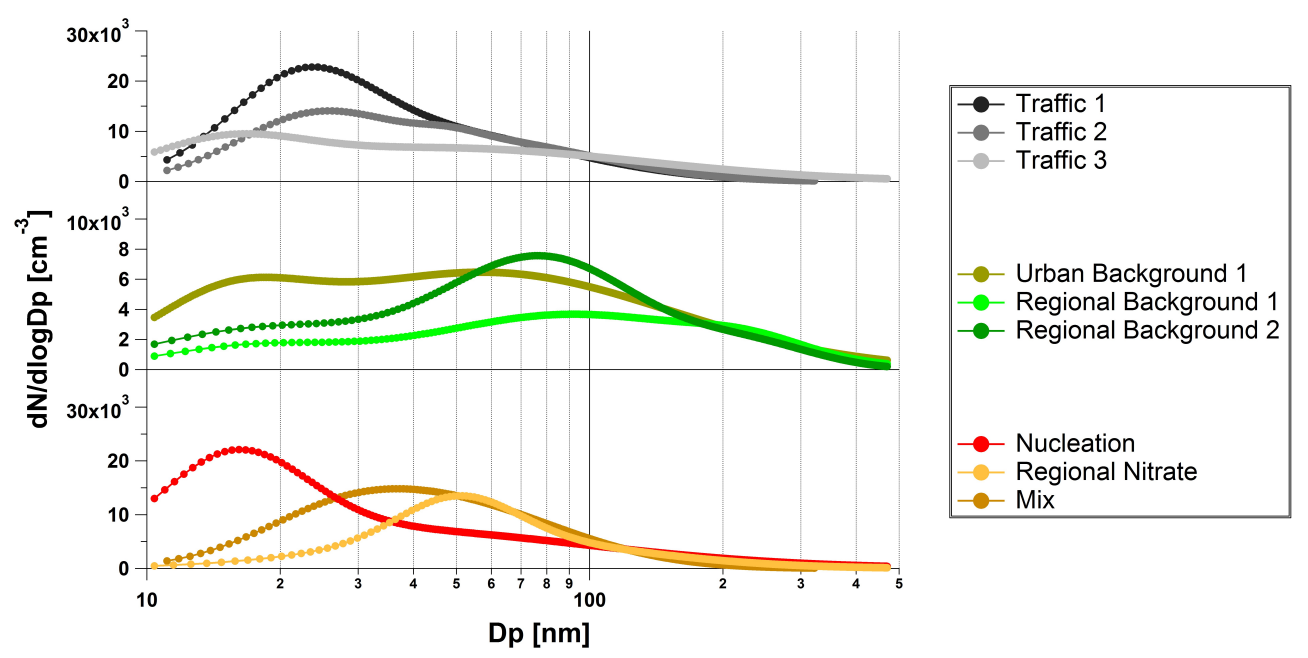

Fig. 1. Aerosol size-resolved distributions of the nine clusters' results from the $k$-means analysis performed on the SMPS data at all SAPUSS monitoring sites.

Table 2. Summary of the lognormal fitting of the 9 clusters separated into the nucleation, Aitken and accumulation modes. Peak maximum values were found between 15 and $24 \mathrm{~nm}$ for the nucleation mode, 33-77 nm for the Aitken mode and particles larger than $100 \mathrm{~nm}$ correspond to the accumulation mode. The total area percentage for each peak is also indicated.

\begin{tabular}{lllll}
\hline Type & $k$-means cluster & nucleation & Aitken & accumulation \\
\hline \multirow{3}{*}{ Traffic } & Traffic 1 & $23 \pm 1 \mathrm{~nm}(21 \%)$ & $33 \pm 6 \mathrm{~nm}(79 \%)$ & - \\
& Traffic 2 & $24 \pm 1 \mathrm{~nm}(4 \%)$ & $34 \pm 1 \mathrm{~nm}(96 \%)$ & - \\
& Traffic 3 & $15 \pm 1 \mathrm{~nm}(6 \%)$ & $42 \pm 4 \mathrm{~nm}(94 \%)$ & - \\
\hline \multirow{3}{*}{ Background Pollution } & Urban Background 1 & $16 \pm 1 \mathrm{~nm}(2 \%)$ & $53 \pm 1 \mathrm{~nm}(98 \%)$ & - \\
& Regional Background 1 & $20 \pm 2 \mathrm{~nm}(4 \%)$ & $51 \pm 3 \mathrm{~nm}(9 \%)$ & $135 \pm 8 \mathrm{~nm}(87 \%)$ \\
& Regional Background 2 & $17 \pm 1 \mathrm{~nm}(2 \%)$ & $77 \pm 1 \mathrm{~nm}(98 \%)$ & - \\
\hline \multirow{3}{*}{ Special case } & Nucleation & $15 \pm 1 \mathrm{~nm}(16 \%)$ & $28 \pm 5 \mathrm{~nm}(84 \%)$ & - \\
& Regional Nitrate & - & $52 \pm 1 \mathrm{~nm}(100 \%)$ & - \\
& Mix & - & $39 \pm 1 \mathrm{~nm}(100 \%)$ & - \\
\hline
\end{tabular}

four sites and had very dynamic characteristics. It was found more frequently at the $\mathrm{UB}_{\text {site }}$ and the $\mathrm{TC}_{\text {site }}$ (around $25 \%$ of hours at each site) in contrast to the $15 \%$ of hours registered at both $\mathrm{RS}_{\text {site }}$ and $\mathrm{RB}_{\text {site }}(\mathrm{Ta}-$ ble 1). On the other hand, clusters describing a Regional Background pollution environment $\left(\mathrm{RB}_{\text {clus_ } 1}\right.$ and $\mathrm{RB}_{\text {clus_2 }}$ ) were found more commonly at the $\mathrm{SA}^{-}$ PUSS monitoring sites not affected by anthropogenic sources. This is the case of the $\mathrm{RB}_{\text {clus_1 } 1}$ cluster, seen at the $\mathrm{RB}_{\text {site }}, \mathrm{UB}_{\text {site }}$ and $\mathrm{TC}_{\text {site }}$ for 22,19 , and $18 \%$

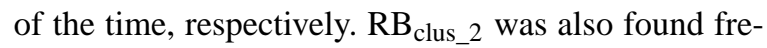
quently at the $\mathrm{RB}_{\text {site }}(39 \%)$, followed by $\mathrm{UB}_{\text {site }}(17 \%)$ and $\mathrm{TC}_{\text {site }}(15 \%)$.

- Three clusters (Nucleation - $\mathrm{NU}_{\text {clus }}$; Regional Nitrate - NIT $_{\text {clus }}$; and Mix - MIX clus) associated with "Special cases" accounted for the remaining $16 \%$ of the aerosol size distribution overall population. The NU cluster was seen primarily at the urban background stations and rarely at the $\mathrm{RS}_{\text {site }}$ or the $\mathrm{RB}_{\text {site }}$. The NIT cluster occurred mostly at the $\mathrm{RB}_{\text {site, }}$, while the MIX cluster (the least characterised among all) was observed in almost the same proportion at all sites except for the $\mathrm{UB}_{\text {site }}$ (Table 1).

Figure 1 shows the particle size distribution for each of the nine clusters. In order to support the interpretation of this figure, the log-normal fitting modes of each cluster and their modal diameters and mode area percentages are presented in Fig. S1 and Table 2, respectively. Furthermore, Table 3 shows the dominant air mass for each cluster presented. This is achieved following the procedure described in Dall'Osto et al. (2013b), classifying the air mass origin of each day of the campaign as Atlantic (ATL), European-Mediterranean (EUR), North African east (NAF_E), North African west (NAF_W) or Regional (REG). Additionally, the average values of air pollutant and meteorological parameters can be found in Table 4, and the diurnal trends are shown in Fig. 2. It 
Table 3. Air mass origin dominating at each cluster (average percentage values). The air mass types are Atlantic (ATL), Regional (REG), North African west (NAF_W), North African east (NAF_E) and European (EUR).

\begin{tabular}{lll}
\hline Type & $k$-means cluster & $\begin{array}{l}\text { Dominant } \\
\text { air mass }\end{array}$ \\
\hline \multirow{3}{*}{ Traffic } & Traffic 1 & $56 \%$ REG \\
& Traffic 2 & $39 \%$ REG \\
& Traffic 3 30 ATL \\
\hline \multirow{3}{*}{ Background Pollution } & Urban Background 1 & $35 \%$ REG \\
& Regional Background 1 & $57 \%$ REG \\
& Regional Background 2 & $49 \%$ NAF E \\
\hline \multirow{3}{*}{ Special case } & Nucleation & $78 \%$ ATL \\
& Regional Nitrate & $50 \%$ REG \\
& Mix & $63 \%$ ATL \\
\hline
\end{tabular}

should be noted that clusters showing a lower incidence than 30 counts (hours) at any site were not considered. According to the data obtained, each cluster can be described as follows:

\subsubsection{Traffic-related clusters}

- $\mathrm{T}_{\text {clus_1 }}$ represents $8 \%$ of the total sample and is exclusively observed at the $\mathrm{RS}_{\text {site }}(24 \%)$. It presents one of the highest $\mathrm{N}$ values, showing a bimodal size distribution with a well-defined nucleation size mode at $23 \pm 1 \mathrm{~nm}$ and a broad Aitken mode at $33 \pm 6 \mathrm{~nm}$ (Fig. 1, Table 2, Fig. S1a). It is associated with high concentration levels of traffic pollutants such as $\mathrm{BC}\left(3.3 \pm 1.4 \mu \mathrm{g} \mathrm{m}^{-3}\right)$, $\mathrm{NO}\left(9 \pm 7 \mu \mathrm{g} \mathrm{m}^{-3}\right)$ and $\mathrm{NO}_{2}$ $\left(39 \pm 15 \mu \mathrm{g} \mathrm{m}^{-3}\right.$, Fig. S3c, S2e, f). Regarding particle mass it shows high $\mathrm{PM}_{10}$ concentration values $\left(34 \pm 15 \mu \mathrm{g} \mathrm{m}^{-3}\right)$ and also high $\mathrm{N}$ values in the nucleation mode $\mathrm{N}_{15-30 \mathrm{~nm}}\left(2.1 \times 10^{3} \mathrm{~cm}^{-3}\right)$, as shown in Table 4. It also has the lowest relative humidity $(54 \pm 16 \%)$ of all clusters at the $\mathrm{RS}_{\text {site }}$ and occurs mainly in the afternoon and early evening (Fig. 2b).

- $\mathrm{T}_{\text {clus_2 }}$ prevails during $13 \%$ of the time and is the dominant cluster at the $\mathrm{RS}_{\text {site }}(47 \%)$. Like cluster $\mathrm{T}_{\text {clus_1 }}$, it shows a bimodal particle size distribution peaking at $24 \pm 1 \mathrm{~nm}$ and $34 \pm 1 \mathrm{~nm}$, and it has similar concentration values of $\mathrm{BC}\left(3.3 \pm 1.7 \mu \mathrm{g} \mathrm{m}^{-3}\right)$, NO $\left(8 \pm 8 \mu \mathrm{g} \mathrm{m}^{-3}\right)$ and $\mathrm{NO}_{2}\left(39 \pm 18 \mu \mathrm{g} \mathrm{m}^{-3}\right)$. The most important difference between this cluster and the previous traffic cluster $\left(\mathrm{T}_{\text {clus_1 }}\right.$ ) is that this one is associated with higher RH conditions (67 \pm 11 versus $54 \pm 16 \%)$. It also contains less particles in the nucleation mode range $\mathrm{N}_{15-30 \mathrm{~nm}}\left(1.3 \times 10^{3} \mathrm{~cm}^{-3}\right.$ and $2.1 \times 10^{3} \mathrm{~cm}^{-3}$, respectively). This points to an opposite trend between RH and ultrafine particle concentrations, as further discussed in Sect. 4.3. This cluster correlates temporally with the morning rush hour

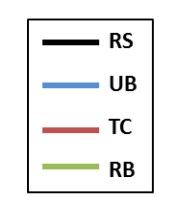

(a)

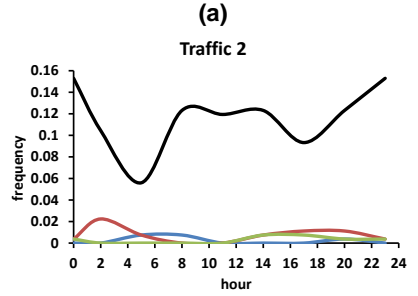

(c)

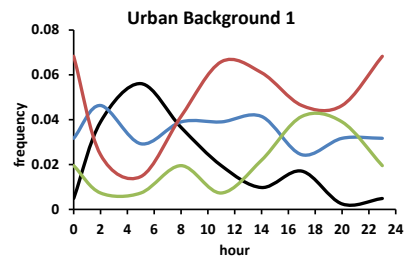

(e)

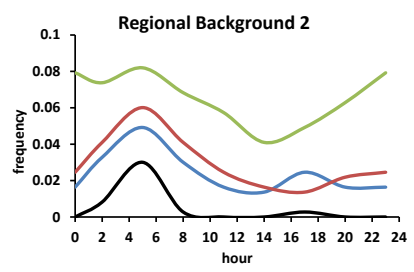

(a)

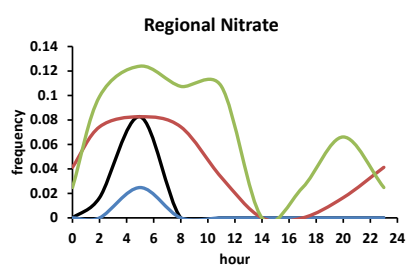

(i)

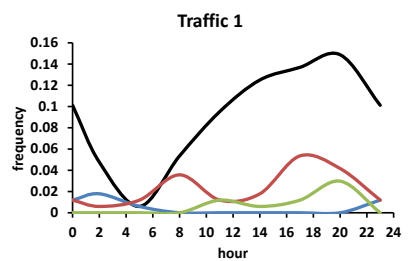

(b)

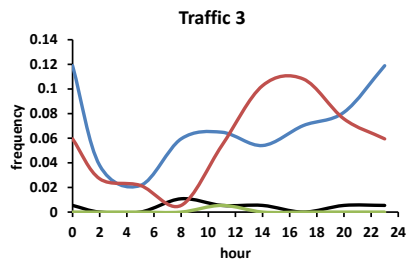

(d)

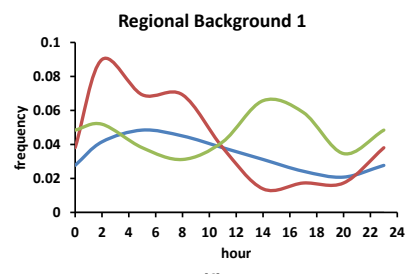

(f)

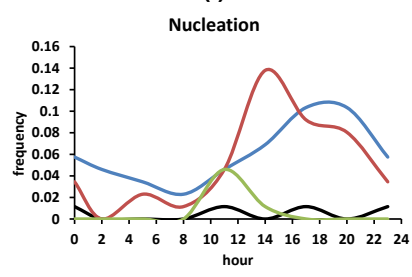

(h)

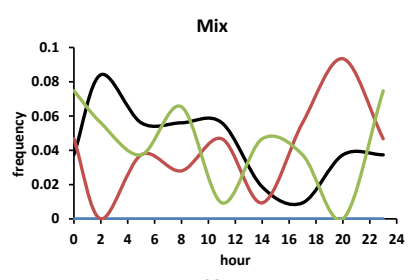

(j)
Fig. 2. Daily trends for each $k$-means cluster at the 4 sites $\left(\mathrm{RS}_{\text {site }}\right.$, $\mathrm{UB}_{\text {site }}, \mathrm{TC}_{\text {site }}$ and $\mathrm{RB}_{\text {site }}$ ); (a) legend, (b) Traffic 1, (c) Traffic 2, (d) Traffic 3, (e) Urban Background 1, (f) Regional Background 1, (g) Regional Background 2, (h) Nucleation, (i) Regional Nitrate and (j) Mix.

(8 a.m.) and is maintained until the afternoon ( 2 p.m.). Its frequency rises again coinciding with the evening rush hour (8 p.m.) as can be seen in Fig. 2c.

- $\mathrm{T}_{\text {clus_3 }}$ prevails $9 \%$ of the time and characterises the traffic environment detected at the urban background stations of $\mathrm{UB}_{\text {site }}(22 \%)$ and $\mathrm{TC}_{\text {site }}(14 \%)$. Like $\mathrm{T}_{\text {clus_1 }}$ and $\mathrm{T}_{\text {clus_2 }}, \mathrm{T}_{\text {clus_3 }}$ also shows a bimodal distribution with one peak in the nucleation size mode and a second in the Aitken mode, although with different size modes (a much reduced nucleation mode at $15 \pm 1 \mathrm{~nm}$ and broader Aitken mode at $42 \pm 4 \mathrm{~nm}$, 


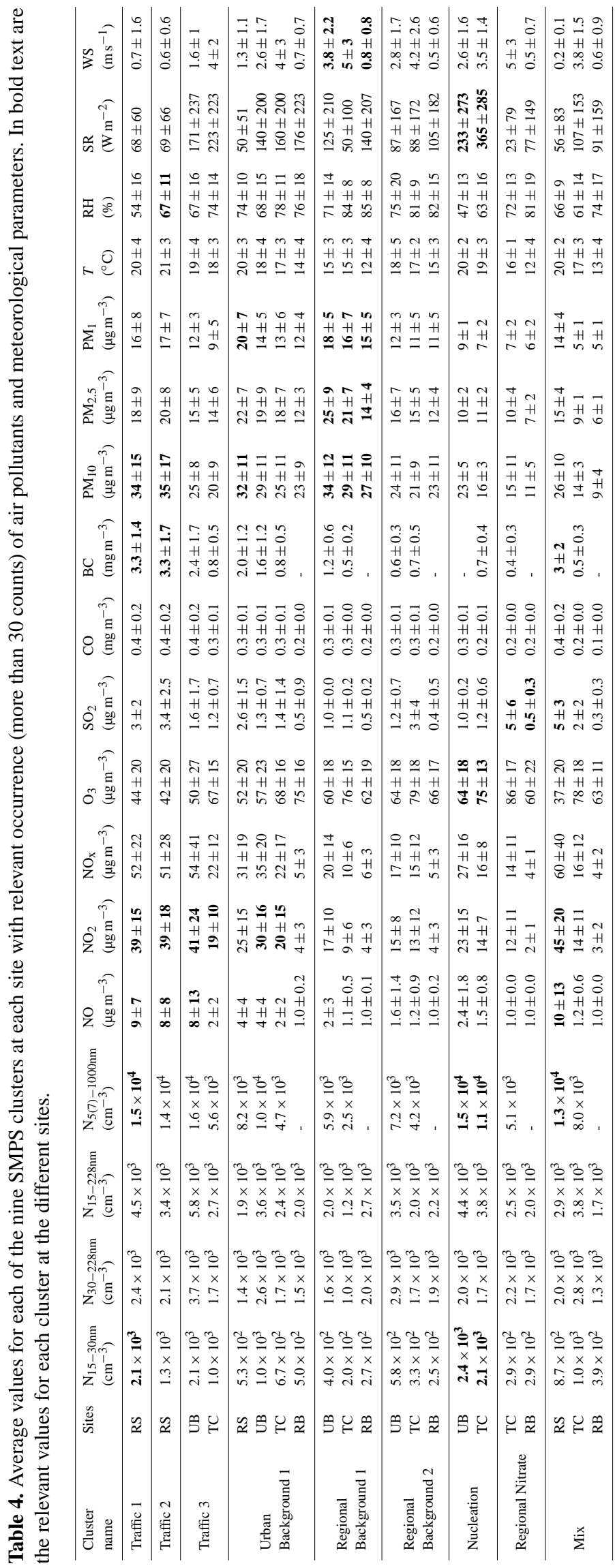


respectively; see Table 2). $\mathrm{T}_{\text {clus } \_3}$ is associated with the highest levels of traffic pollutants at the urban background $\mathrm{UB}_{\text {site }}$ and $\mathrm{TC}_{\text {site }}$, with traffic gaseous average concentrations similar to $\mathrm{T}_{\text {clus_1 }}$ and $\mathrm{T}_{\text {clus_2 }}$ (see Fig. S2e, f, g). However, it presents the lowest $\mathrm{N}$ concentrations among the three traffic clusters (Table 4). Furthermore, $\mathrm{T}_{\text {clus_3 } 3}$ is related to the predominance of Atlantic air masses. This is in contrast to $\mathrm{T}_{\text {clus_1 } 1}$ and $\mathrm{T}_{\text {clus_2 }}$, which are found under regional stagnant air mass conditions (see Table 3). $\mathrm{T}_{\text {clus__3 }}$ occurred mainly during the daylight hours and late evening at $\mathrm{UB}_{\text {site }}$, and reaches $\mathrm{TC}_{\text {site }}$ at midday due to transport by the sea breeze circulation (Fig. 2d). Further consideration on the difference among the three traffic-related clusters is given in Sect. 4 .

\subsubsection{Background pollution clusters}

- Urban Background $1\left(\mathrm{UB}_{\text {clus_ } 1}\right)$ is the most prevalent of all clusters ( $21 \%$ of the time) as it has a significant occurrence at all the four monitoring sites (Table 1). However, it occurs more frequently at the urban background sites $\left(\mathrm{UB}_{\text {site }}: 28 \%\right.$; $\left.\mathrm{TC}_{\text {site }}: 26 \%\right)$. Like the traffic clusters, it exhibits a bimodal distribution with a small nucleation size mode $(16 \pm 1 \mathrm{~nm})$ and a broader Aitken mode $(53 \pm 1 \mathrm{~nm})$. Nevertheless, it is important to note that the nucleation mode is less pronounced in comparison to the Traffic clusters and $\mathrm{N}$ concentrations are lower (Fig. 1, Tables 2, 4). This cluster is also affected by moderate levels of traffic pollutants: e.g. at the $\mathrm{RS}_{\text {site }}$ the level of $\mathrm{NO}_{2}$ reached $25 \pm 15 \mu \mathrm{g} \mathrm{m}{ }^{-3}$. This background cluster prevails during nighttime at the $\mathrm{RS}_{\text {site }}$, likely representing the cleanest conditions at the road monitoring site. By contrast, at the $\mathrm{UB}_{\text {site }}$ this cluster does not show a clear diurnal variation, confirming its urban background nature (Fig. 2e). It is interesting to note that this cluster was monitored during the morning in the hilly background environment $\left(\mathrm{TC}_{\text {site }}\right)$ and later on in the afternoon at the regional $\mathrm{RB}_{\text {site }}$. This suggests that the urban background pollution (represented by this cluster, and hence named after it) can be transported by the sea breeze circulation from the city centre to the regional background (Fig. 2e).

- The Regional Background Pollution 1 (RB clus_1 $_{1}$ ) cluster prevails $15 \%$ of the time and is present at all sites except at the $\mathrm{RS}_{\text {site }}$. At the $\mathrm{RB}_{\text {site }}$ it accounts for $22 \%$ of the time, while at the urban background $\mathrm{UB}_{\text {site }}$ and $\mathrm{TC}_{\text {site }}$ represent 19 and $18 \%$, respectively. This cluster was the only one to have a tri-modal size distribution, with size modes at $20 \pm 2,51 \pm 3$ and $135 \pm 8 \mathrm{~nm}$, the accumulation mode being the dominant one (Table 2). It shows the highest PM concentrations of all clusters for $\mathrm{UB}_{\text {site }}, \mathrm{TC}_{\text {site }}$ and $\mathrm{RB}_{\text {site }}$ (e.g. at $\mathrm{UB}_{\text {site }}$ $\mathrm{PM}_{10}$ is $34 \pm 12 \mu \mathrm{g} \mathrm{m}^{-3}, \mathrm{PM}_{2.5}$ is $25 \pm 9 \mu \mathrm{g} \mathrm{m}^{-3}$ and
$\mathrm{PM}_{1}$ is $18 \pm 5 \mu \mathrm{g} \mathrm{m}^{-3}$; Table 4). It is also associated with the highest wind speed values of all clusters at $\mathrm{UB}_{\text {site }}\left(3.8 \pm 2.2 \mathrm{~m} \mathrm{~s}^{-1}\right), \mathrm{TC}_{\text {site }}\left(5 \pm 3 \mathrm{~m} \mathrm{~s}^{-1}\right)$ and $\mathrm{RB}_{\text {site }}\left(0.8 \pm 0.8 \mathrm{~ms}^{-1}\right)$. Figure $2 \mathrm{f}$ shows that it prevails during the night in $\mathrm{TC}_{\text {site, }}$, when the site is less influenced by the urban background. At the $\mathrm{UB}_{\text {site }}$ it occurs regardless of the hour, suggesting that regional background size distributions can also describe the lowest urban background conditions at the $\mathrm{UB}_{\text {site }}$.

- The Regional Background Pollution $2\left(\mathrm{RB}_{\text {clus_2 }}\right)$ cluster occurs more often at the regional background $\mathrm{RB}_{\text {site }}$ $(39 \%)$ and then decreases in occurrence as we come close to the city: $\mathrm{TC}_{\text {site }}(15 \%)$ and $\mathrm{UB}_{\text {site }}(17 \%)$. It has a small nucleation size mode at $17 \pm 1 \mathrm{~nm}$ and a dominant Aitken mode at $77 \pm 1 \mathrm{~nm}$. Regarding the diurnal trends (Fig. 2g) it can be observed that it is similar at all four sites, peaking at night. The main differences between $\mathrm{RB}_{\text {clus_1 } 1}$ and $\mathrm{RB}_{\text {clus_2 }}$ clusters is that the first one accounts for aged and long-transport aerosols (high loading of PM mass, Table 4) and is dominated by the accumulation mode (Table 2). By contrast, cluster $\mathrm{RB}_{\text {clus_2 }}$ presents a broad peak in the Aitken mode with higher $\mathrm{N}$ and lower mass concentration levels. Further discussion can be found in Sect. 4.1.

\subsubsection{Minor clusters}

- The Nucleation cluster $\left(\mathrm{NU}_{\text {clus }}\right)$ represents only $5 \%$ of all observations and occurs mainly at the urban background $\mathrm{UB}_{\text {site }}$ and $\mathrm{TC}_{\text {site }}$ (11 and $6 \%$, respectively). It has a main nucleation size mode at $15 \pm 1 \mathrm{~nm}$ and a small Aitken mode at $28 \pm 5 \mathrm{~nm}$ (Fig. S1g). This cluster prevails under intense solar radiation at both $\mathrm{UB}_{\text {site }}$ $\left(233 \pm 273 \mathrm{Wm}^{-2}\right)$ and $\mathrm{TC}_{\text {site }}\left(365 \pm 285 \mathrm{Wm}^{-2}\right)$ as well as relatively high ozone concentrations at $\mathrm{UB}_{\text {site }}\left(64 \pm 18 \mu \mathrm{g} \mathrm{m}^{-3}\right)$ and $\mathrm{TC}_{\text {site }}\left(75 \pm 13 \mu \mathrm{g} \mathrm{m}^{-3}\right.$, Table 4, Fig. S2, S3). The high total $\mathrm{N}$ concentrations $\left(1.5 \times 10^{4} \mathrm{~cm}^{-3}\right.$ at $\mathrm{UB}_{\text {site }}$ and $1.1 \times 10^{4} \mathrm{~cm}^{-3}$ at $\left.\mathrm{TC}_{\text {site }}\right)$ and the concentration for the nucleation mode $\mathrm{N}_{15-30 \mathrm{~nm}}$ at both $\mathrm{UB}_{\text {site }}\left(2.4 \times 10^{3} \mathrm{~cm}^{-3}\right)$ and $\mathrm{TC}_{\text {site }}\left(2.1 \times 10^{3} \mathrm{~cm}^{-3}\right)$ should also be noted. The diurnal trends also confirm that this cluster is associated with photochemical nucleation events peaking during the afternoon and early evening at the $\mathrm{UB}_{\text {site }}(14-20 \mathrm{~h})$ and $\mathrm{TC}_{\text {site }}(12-15 \mathrm{~h})$, respectively (Fig. 2h). This cluster was found to describe well the nucleation events described in detail elsewhere in this ACP SAPUSS special issue (Dall'Osto et al., 2013a). However, it should be noted that during this study only particles above $15 \mathrm{~nm}$ were monitored due to the SMPS configurations. Therefore, the $\mathrm{NU}_{\text {clus }}$ accounts for the nucleating particles that have grown to such detectable sizes - thus leading to an underestimation of the early stage nucleation processes. It is 
also of note that the frequency of this $\mathrm{NU}_{\text {clus }}$ increase in June-August (Dall'Osto et al., 2012) compared to September-October (this study).

- The Regional Nitrate cluster represents $6 \%$ of the total, and occurs predominantly at the $\mathrm{TC}_{\text {site }}(7 \%)$ and $\mathrm{RB}_{\text {site }}(14 \%)$. It exhibits a unimodal aerosol size distribution peaking at $52 \pm 1 \mathrm{~nm}$ (Fig. S1h). It is found to peak mainly during nighttime (Fig. 2i). This mode is smaller than a similar $k$-means cluster (cluster regional, $90 \pm 12 \mathrm{~nm}$ ) found in the clustering analysis of Dall'Osto et al. (2012) for the whole year 2004 in the urban area of Barcelona. In this regard, it is interesting to note that the nitrate cluster of this study was found to occur mainly at the $\mathrm{TC}_{\text {site }}$ and $\mathrm{RB}_{\text {site }}$, the two sites that are away from the urban city centre, suggesting different aerosol size distributions for urban background (Dall'Osto et al., 2012) and regional background nitrate (this study). Additionally, SAPUSS measurements were restricted to the autumn season, whereas the previous study included a whole year of measurements (Dall'Osto et al., 2012). It is likely that the larger-sized mode of the previous study reflects the wintertime high nitrate mass loadings not monitored during this intensive SAPUSS field campaign.

- The Mix cluster occurs 6-7\% of the time at the $\mathrm{RS}_{\text {site, }}$, $\mathrm{TC}_{\text {site }}$ and $\mathrm{RB}_{\text {site. }}$ It exhibits a unimodal size distribution with a peak in the Aitken mode at $39 \pm 1 \mathrm{~nm}$ (Table 2). The temporal trends and the average values of the air quality parameters were not well defined (Fig. 2j, Table 4), likely due to a mix of sources and atmospheric processes describing this factor. This factor cannot be associated with any specific source and was found to be the least well defined of all the nine clusters. It is associated with high concentrations of traffic-related pollutants (NO, $\mathrm{CO}$ and black carbon) and $\mathrm{SO}_{2}$, but is clearly not heavily influenced by fresh traffic emissions.

\section{Discussion}

\subsection{Size distributions}

The results presented above were expected in the sense that the monitoring sites closest to traffic pollution are the ones most influenced by vehicle exhaust emissions (Traffic $k$ means category). In contrast, when moving away from the city centre, the particle size distributions are mainly described by the $k$-means clusters representative of the background conditions (Background Pollution $k$-means category). The dominant clusters at $\mathrm{RS}_{\text {site }}\left(\mathrm{T}_{\text {clus_1 } 1}\right.$ and $\mathrm{T}_{\text {clus_2 }}$ ) show very similarly size modes in the nucleation and Aitken sizes, centred between 20 and $35 \mathrm{~nm}$ and typical of roadside aerosol size distributions (Charron and Harrison 2003;
Rönkkö et al., 2007; Dall'Osto et al., 2011a). The finest mode $\left(23 \pm 1 \mathrm{~nm}\right.$ for $\mathrm{T}_{\text {clus_1 } 1}$ and $24 \pm 1 \mathrm{~nm}$ for $\left.\mathrm{T}_{\text {clus_2 }}\right)$ is well defined (Fig. S1a, b) and can be attributed to particles generated from vehicle exhaust emissions. The Aitken mode, peaking at $33 \pm 6 \mathrm{~nm}$ and $34 \pm 1 \mathrm{~nm}\left(\mathrm{~T}_{\text {clus_1 }}\right.$ and $\mathrm{T}_{\text {clus_ } 2}$, respectively), is broader than the nucleation ones (see Fig. S1a, b). This mode is somehow in between the position of the modes at around $20 \mathrm{~nm}$ associated with nucleation mode particles generated during dilution of diesel exhaust emissions (Ntziachristos et al., 2007) and at around 50-60 nm corresponding to solid carbonaceous particles from diesel exhaust (Shi et al., 2000; Harrison et al., 2011). Out of the two Traffic clusters at $\mathrm{RS}_{\text {site }}, \mathrm{T}_{\text {clus_2 }}$ reflects the traffic rush hour diurnal variation (Fig. 2c) and is therefore more representative of fresh vehicle exhaust emissions. By contrast, $\mathrm{T}_{\text {clus_1 }}$ is seen mainly during daytime (Fig. 2b) and is more affected by other sources and meteorological conditions (lower RH). $\mathrm{T}_{\text {clus_1 }}$ has a wider nucleation mode area ( $21 \%$; see Table 2$)$ whilst $\mathrm{T}_{\text {clus_2 }}$ shows a higher dominance of the Aitken mode (96\% of the total area).

When moving away from the traffic hot spot emission sources $\left(\mathrm{RS}_{\text {site }}\right)$, the aerosol size distributions describing such sources showed a strikingly different aerosol size mode. This is well seen in our study of cluster $T_{\text {clus_3 }}$, which is the one that best describes the diluted traffic conditions detected at the urban background sites ( $\mathrm{UB}_{\text {site }}$ and $\left.\mathrm{TC}_{\text {site }}\right)$. In this case, the nucleation mode peak is found reduced in diameter by $25 \%$ (at $15 \mathrm{~nm}$ ) relative to the nucleation mode detected at the $\mathrm{RS}_{\text {site. }}$ Moreover, there is a loss of area under the nucleation mode (Fig. 1), which also means a loss of particle number within the $15-228 \mathrm{~nm}$ size range. This suggests that primary particles originating close to traffic sources (around $20 \mathrm{~nm}$ mode, like $\mathrm{T}_{\text {clus_1 }}$ and $\mathrm{T}_{\text {clus_2 }}$ nucleation mode peaks) can reduce their sizes by evaporation processes during advection to the urban background site, thus leading to a shift towards smaller-sized modes (Dall'Osto at al., 2011a; Harrison et al., 2012). On the other hand, the modal diameter of the Aitken mode of cluster $T_{\text {clus_3 }}(42 \mathrm{~nm})$ is larger than the other two traffic clusters ( $33 \mathrm{~nm}$ for $T_{\text {clus_1 }}$ and $34 \mathrm{~nm}$ for $T_{\text {clus_2 }}$ ), suggesting that coagulation and condensation can occur in the Aitken mode. This shows that fine organic carbon (OC) mode aerosols (more volatile) tend to evaporate whereas the solid elemental carbon (EC) aerosols (more stable) do not (Dall'Osto et al., 2011; Harrison et al., 2012).

The size distribution of cluster $\mathrm{UB}_{\text {clus_1 }}$ suggests that it contains evaporating aerosols (nucleation peak located at $16 \mathrm{~nm}$ ) but also aged aerosols with an anthropogenic origin (Aitken peak at $53 \mathrm{~nm}$ ). The latter may also represent the involatile solid graphite particles in vehicle exhaust (Harrison et al., 2011). This cluster describes the urban background pollution, which can reach the suburban $\left(\mathrm{TC}_{\text {site }}\right)$ and regional monitoring $\left(\mathrm{RB}_{\text {site }}\right)$ sites during the afternoon sea breeze circulation (Dall'Osto et al., 2013b). An example of this aerosol transport and evolution of size distributions can be seen for the day 28 September 2010 (Table S1, Fig. S4). 


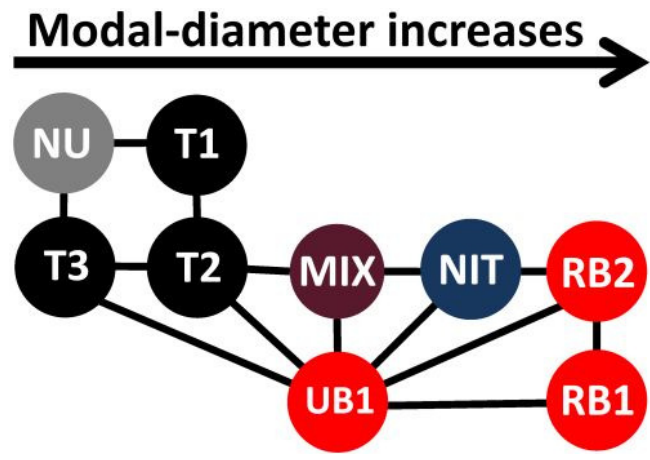

Fig. 3. Cluster proximity diagram during SAPUSS. In black are Traffic-related clusters (T1, T2, T3); in red background clusters (UB1, RB1, RB2); and in grey, purple and blue the special cases (NU, MIX and NIT).

By contrast, a very different scenario was found at the $\mathrm{RB}_{\text {site }}$, dominated by background clusters ( $\mathrm{RB}_{\text {clus_1 } 1}$ and

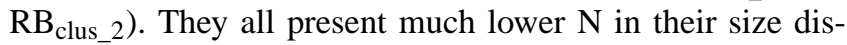
tributions in comparison to the Traffic clusters (Fig. 1). The $\mathrm{RB}_{\text {clus_1 }}$ cluster is found under Regional air mass conditions; it shows low $\mathrm{N}$ and a dominant accumulation mode, thus pointing to aged anthropogenic aerosols, typical of regional recirculation of air masses. In addition, high PM concentrations are measured for $\mathrm{RB}_{\text {clus } 11}$ in the urban and rural background stations.

Regarding the minor clusters, the most relevant is the Nucleation cluster, showing that photo-nucleation processes occur in urban environments in southern Mediterranean areas, primarily in urban and suburban background scenarios when the solar radiation is very intense (Pey et al., 2009; Reche et al., 2011; Dall'Osto et al., 2012). The Regional Nitrate cluster appears more frequently at the $\mathrm{RB}_{\text {site }}$ during nighttime. The Mix cluster was not well defined.

\subsection{SMPS $k$-means clustering results explained by cluster proximity diagram during SAPUSS}

The results described in Sect. 3.1 are graphically summarised by a Cluster Proximity Diagram (CPD) in Fig. 3. The CPD displays how the clusters are arranged relative to each other based on the similarity of the elements in each cluster measured using the Silhouette Width (Beddows et al., 2009). While $k$-means clustering matches together the most similar spectra into the nine clusters (Figs. 1,2), the CPD positions these clusters according to the degree of similarity within each cluster. The more similar the elements within a selection of clusters are, the closer the nodes representing those clusters are placed to each other in the diagram (e.g. $\mathrm{T}_{\text {clus_1 }}$, $\mathrm{T}_{\text {clus_2 } 2}$ and $\mathrm{T}_{\text {clus_3 }}$ ). Using the optimum number of clusters (9), the elements of this selection (e.g. $T_{\text {clus } 11}, T_{\text {clus } 2}$ and $\mathrm{T}_{\text {clus_3 } 3}$ ) are sufficiently similar to each other to be placed next to each other in the diagram, but they are not sufficiently similar to form a new cluster. Likewise, pairs of nodes furthest apart in the diagram represent clusters whose elements are

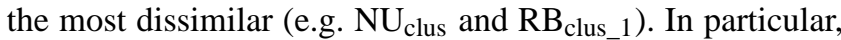
this is illustrated further in Fig. 3 where the average modal diameter of the clusters increases from left to right.

Clusters $T_{\text {clus_1 }}$ and $T_{\text {clus_2 }}$ are associated with primary traffic aerosols and are positioned in the same vertical area of the diagram. Cluster $\mathrm{NU}_{\text {clus }}$ and cluster $\mathrm{T}_{\text {clus_3 } 3}$ are confined in the smallest modal diameters, in the far left part of the CPD. This is due to the atmospheric sources and the processes affecting cluster $\mathrm{NU}_{\text {clus }}$ (new particle formation) and cluster $\mathrm{T}_{\text {clus_3 }}$ (evaporation of traffic-related particles $\mathrm{T}_{\text {clus_1-2 }}$; Dall'Osto et al., 2011a). By contrast, the largest modal diameters detected (right part of $\mathrm{CPD}$, Fig. 3) are associated with regional background clusters ( $\mathrm{RB}_{\text {clus_1 } 1}$ and $\mathrm{RB}_{\text {clus_2 }}$, same vertical position in the CPD). Cluster MIX $\mathrm{X}_{\text {clus }}$ - not well defined - stands in the middle of the CPD and is likely to be a mixture of all sources and processes. By contrast, $\mathrm{NIT}_{\text {clus }}$ stands in a position close to the RB clusters. Finally, it is interesting to note that cluster UB1 (which is associated with the urban background pollution) is linked to all but two ( $\mathrm{NU}_{\text {clus }}$ and $\left.\mathrm{T}_{\text {clus_1 }}\right)$ of the clusters. This suggests that the sources/processes loading clusters $\mathrm{T}_{\text {clus_3 } 3}, \mathrm{~T}_{\text {clus_2 }}$, $\mathrm{MIX}_{\text {clus }}, \mathrm{NIT}_{\text {clus }}, \mathrm{RB}_{\text {clus_2 }}$ and $\mathrm{RB}_{\text {clus_1 }}$ all consequently develop and contribute to urban background aerosol. Clusters $\mathrm{T}_{\text {clus_1 }}$ and $\mathrm{NU}_{\text {clus }}$ are strong ultrafine aerosol sources which are somehow modified (for example by growth or evaporation) before contributing to the urban background aerosol population.

In summary, the main sources of the smallest ultrafine particles detected during SAPUSS are due to secondary processes $\left(\mathrm{NU}_{\text {clus }}\right)$ and the evaporation of traffic-related particles $\left(T_{\text {clus_3 }}\right.$, coming from $T_{\text {clus_1 } 1}$ and $\left.T_{\text {clus_2 }}\right)$. The lowest particle number concentrations and the highest modal diameters are related to regional background conditions $\left(\mathrm{RB}_{\text {clus__ } 1}\right.$, $\mathrm{RB}_{\text {clus_2}}$, NIT $\left.\mathrm{N}_{\text {clus }}\right)$. Finally, all these diverse clusters contribute directly into the urban background general aerosol particle spectra ( $\left.\mathrm{UB}_{\text {clus_1 } 1}\right)$, which is indeed at the centre of Fig. 3.

\subsection{The effect of meteorology on primary traffic emissions and secondary nucleation processes during SAPUSS}

The high values of $\mathrm{N}$ recorded in the urban area of Barcelona can be mainly attributed to primary vehicle exhaust emissions (Pey et al., 2009). However, Reche et al. (2011) showed that in Barcelona nucleation events can occur in the middle of the day all year round, contributing to an average of $54 \%$ of total N (average of year 2009). Indeed, during SAPUSS the particle number concentrations $\left(\mathrm{N}_{>55 \mathrm{~nm}}\right)$ were highly correlated with black carbon (BC, a primary marker for traffic emissions) at all monitoring sites only under strong vehicular traffic influences (this special issue; Dall'Osto et al., 2013a). By contrast, under cleaner atmospheric conditions three types of nucleation and growth events were identified 


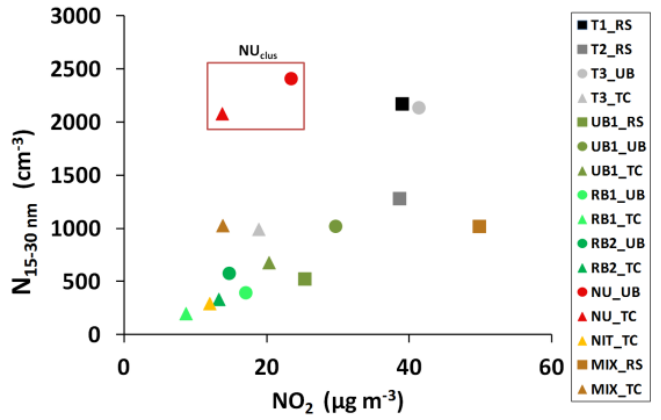

(a)

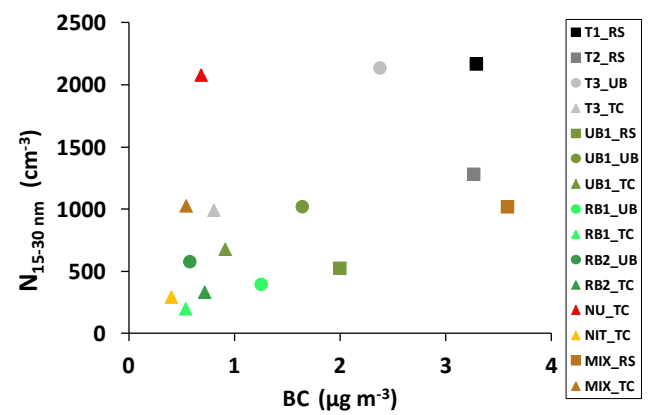

(c)

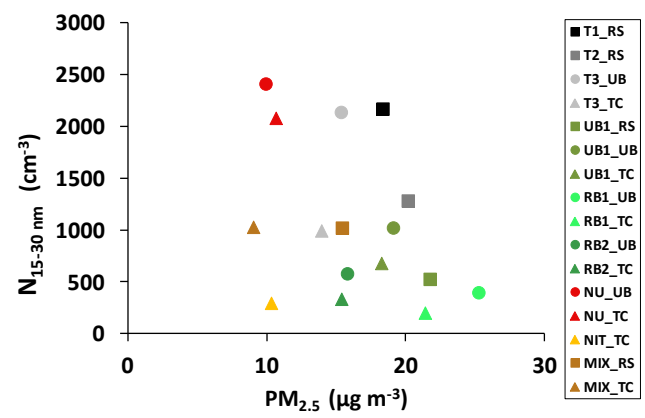

(e)

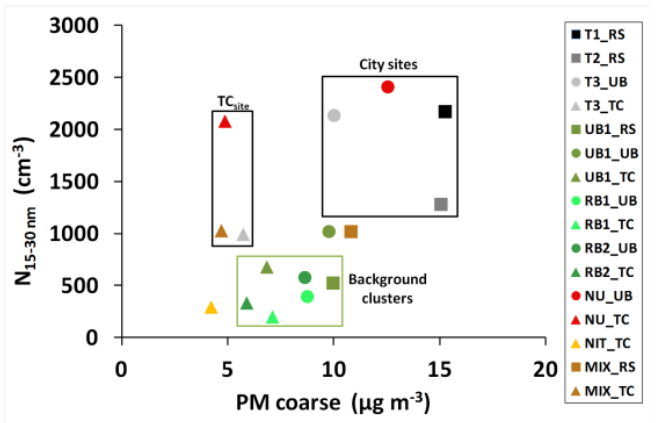

(g)

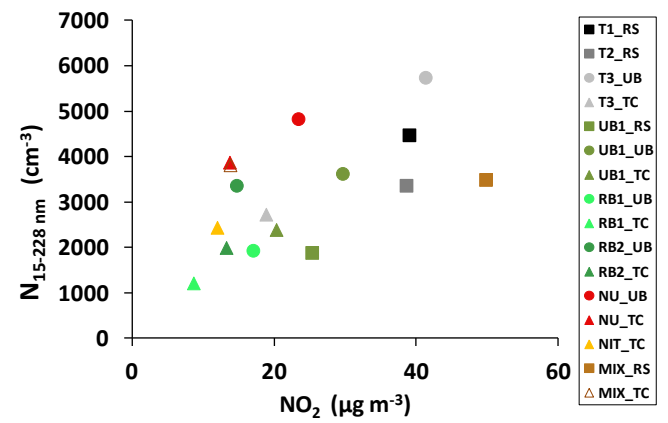

(b)

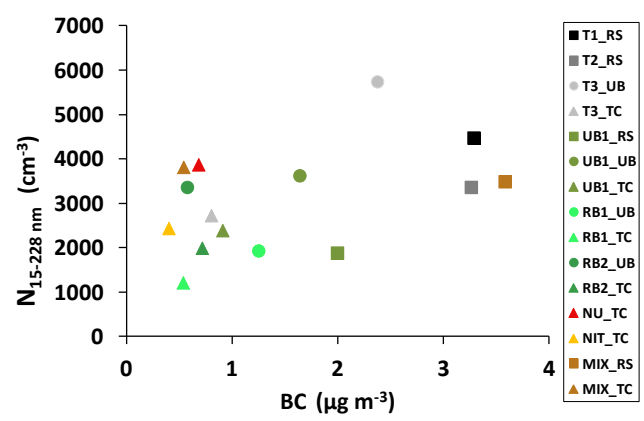

(d)

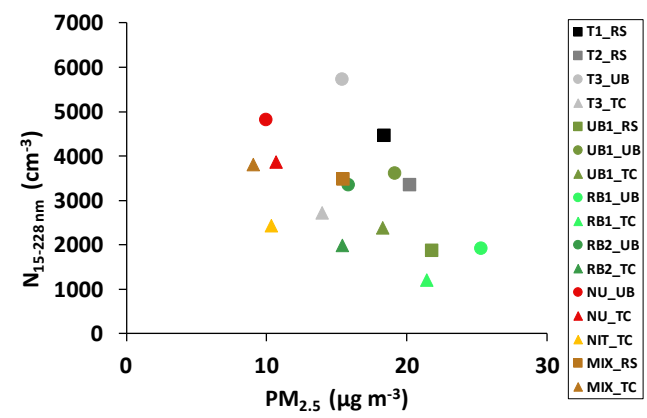

(f)

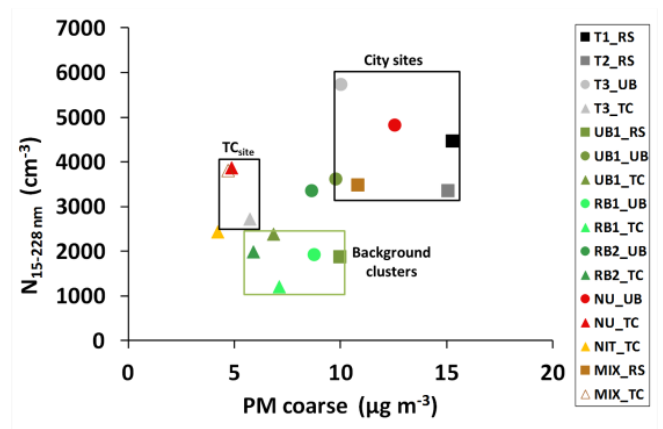

(h)

Fig. 4. Regressions of particle number concentration $(N)$ against air quality parameters and other pollutants. The "Traffic" $k$-means cluster category at all monitoring sites is represented with grey-black dots, the "Background" $k$-means cluster category is coloured in green (light and dark) and the "Special cases" $k$-means cluster category in brown (light and dark): (a) $\mathrm{N}_{15-30 \mathrm{~nm}} \mathrm{vs} \mathrm{NO}_{2}$, (b) $\mathrm{N}_{15-228 \mathrm{~nm}} \mathrm{vs}$. $\mathrm{NO}_{2}$, (c) $\mathrm{N}_{15-30 \mathrm{~nm}}$ vs. BC, (d) $\mathrm{N}_{15-228 \mathrm{~nm}}$ vs. BC, (e) $\mathrm{N}_{15-30 \mathrm{~nm}}$ vs. $\mathrm{PM}_{2.5}$, (f) $\mathrm{N}_{15-228 \mathrm{~nm}}$ vs. $\mathrm{PM}_{2.5}$, (g) $\mathrm{N}_{15-30 \mathrm{~nm}}$ vs. PM $\mathrm{PM}_{\text {coarse }}$, and (h) $\mathrm{N}_{15}-228 \mathrm{~nm}$ vs. $\mathrm{PM}_{\text {coarse }} \mathrm{PM}_{\text {coarse }}$ refers to the fraction $\mathrm{PM}_{10}-\mathrm{PM}_{2.5}$. N concentrations are calculated from the SMPS data. 
(regional only, regional all, urban). An in-depth study of these new particle formation events during SAPUSS can be found under Dall'Osto et al. (2013a). Overall, during SAPUSS the city centre of Barcelona was found to be a source of non-volatile traffic primary particles (29-39\% of $\mathrm{N}_{>5 \mathrm{~nm}}$ ), but other sources, including secondary freshly nucleated particles contributed up to $61-71 \%$ of particle number $\left(\mathrm{N}_{>5 \mathrm{~nm}}\right)$ at all sites (Dall'Osto et al., 2013a).

However, previous studies considering only particles larger than $13 \mathrm{~nm}$ found that photochemically induced nucleation particles make only a small contribution to the total particle number concentration (2-3\% of the total; Dall'Osto et al., 2012). The present study considering aerosol size distributions above $15 \mathrm{~nm}\left(\mathrm{~N}_{>15 \mathrm{~nm}}\right)$ also reports a small percentage of $\mathrm{N}$ ( $<2 \%$ of the total number) associated with nucleation events, calculated by considering the percentage of time the Nucleation cluster occurred (5\%; see Table 1) and the nucleation mode area in it (16\%; see Table 2). In other words, within clean Atlantic air masses, nucleation processes strongly affect $\mathrm{N}_{>55 \mathrm{~nm}}$ concentrations (Reche et al., 2011; Dall'Osto et al., 2013a). However, such particles often fail to grow above the SMPS detection limit of $13 \mathrm{~nm}$ (Dall'Osto et al., 2012) or $15 \mathrm{~nm}$ (this study) in the Mediterranean urban environment.

Less is known on the effect of meteorology on freshly emitted traffic-related ultrafine aerosols in the Mediterranean region. Hence, this section aims to investigate the effect of meteorology on primary traffic emissions. Our objective is to investigate the effect of meteorological parameters on freshly emitted particles from vehicles for a given primary traffic aerosol size distribution. For this purpose, we consider only the traffic hot spot monitoring site $\left(\mathrm{RS}_{\text {site }}\right)$. We therefore monitor a specific SMPS cluster $\left(\mathrm{T}_{\text {clus_2 }}\right.$, Fig. 1 ) which best represents traffic emissions and also shows a good correlation with traffic counts at the RS reported in the SAPUSS overview $\left(R^{2}=0.9\right)$. We additionally removed from this analysis the days dominated by nucleation events (25 September, 5 October, and 17 October 2010) and rain episodes (11 October 2010), thus obtaining a homogeneous data set representative of the average fresh traffic emissions (26 days in total). In other words, we only considered hourly data characterised by a specific aerosol size distribution (SMPS cluster $\left.T_{\text {clus_2 }}\right)$ sampled in a road site hot spot $\left(\mathrm{RS}_{\text {site }}\right)$. This is a unique query which allows us to study how meteorological parameters affect the total $\mathrm{N}$ (measured by CPC, $\mathrm{N}_{5-1000 \mathrm{~nm}}$ ) for a given aerosol size distributions (measured by an SMPS,

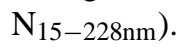

In order to do so, we plotted the ratio of $\mathrm{N}$ measured by the CPC $\left(\mathrm{N}_{>5} \mathrm{~nm}\right)$ and the SMPS $\left(\mathrm{N}_{15-228 \mathrm{~nm}}\right)$ deployed at the road site $\left(\mathrm{RS}_{\text {site }}\right)$ versus key meteorological parameters (wind speed, solar radiation, temperature and $\mathrm{RH}$ ). The ratio $\mathrm{N}_{>5 \mathrm{~nm}} / \mathrm{N}_{15-228 \mathrm{~nm}}$ accounts for particles with diameters mainly between 5 and $15 \mathrm{~nm}$. Perhaps surprisingly, no meteorological variable was found to give a significant correlation with the total particle number ratio, despite earlier stud- ies (e.g. Charron and Harrison, 2003) finding an inverse relationship to temperature, and a positive relationship with wind speed. It therefore appears likely that other factors such as the road traffic composition and local condensation sink are more important in influencing the nanoparticle number concentration at the $\mathrm{RS}_{\text {site. Figure S5 shows hourly values of }}$ RH versus $\mathrm{N}_{5-1000} / \mathrm{N}_{15-228}$, where the solid circle points are also coloured as a function of the air mass origin (ATL: Atlantic; REG: Regional; NAF_W: North African west; and NAF_E: North African east). Figure S5 suggests that for a specific aerosol size distribution associated with primary traffic emissions $\left(T_{\text {clus_2 }}\right)$, there is a very high variability of ultrafine particles in the range $5-15 \mathrm{~nm}$. However, the trend is not significant $\left(R^{2}<0.1\right)$ for the hourly values (Fig. S5). These findings highlight the difficulty of establishing meaningful standards for vehicle emissions based upon particle number concentration given the highly remarkable dynamics of traffic-related particles in the urban atmosphere (Dall'Osto et al., 2011a; Fujitani et al., 2012; Li et al., 2013).

\subsection{Correlations of $\mathrm{N}$ with air quality parameters}

The current European directive on air quality (2008/50/CE) is based on particle mass although mass concentration limit values do not protect against high N (Atkinson et al., 2010). Figure 4 shows several plots of $\mathrm{N}_{15-30 \mathrm{~nm}}$ and $\mathrm{N}_{15-228 \mathrm{~nm}}$ versus selected air pollutant concentrations $\left(\mathrm{NO}_{2}, \mathrm{BC}, \mathrm{PM}_{2.5}\right.$ and $\mathrm{PM}_{2.5-10}$ ). Each point shows the average value of $\mathrm{N}_{\mathrm{x}}$ versus an average of a specific air quality parameter for each of the $k$-means clusters obtained at each monitoring site.

Average parameters that presented less than 30 total counts for each $k$-mean cluster were omitted from the diagrams presented in Fig. 4. Figure 4 shows that the current SMPS SAPUSS data sets can be greatly simplified, allowing a better description of the airborne particle number concentrations and their correlations with other air quality parameters.

Figure $4 \mathrm{a}$ and $\mathrm{b}$ show the $\mathrm{NO}_{2}$ concentrations correlating with $\mathrm{N}$, given that the most polluted clusters are the Traffic ones (black spots), followed by $\mathrm{UB}_{\text {clus_1 }}, \mathrm{RB}_{\text {clus_1 }}$

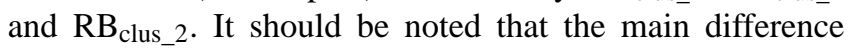
between $\mathrm{N}_{15-30} / \mathrm{NO}_{2}$ and $\mathrm{N}_{15-228} / \mathrm{NO}_{2}$ is given by the

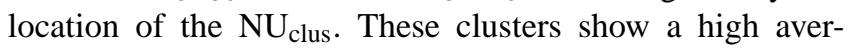
age $\mathrm{N}\left(2000-2500 \mathrm{~cm}^{-3}\right)$ but an intermediate $\mathrm{NO}_{2}$ concentration (15-25 $\mathrm{g} \mathrm{m}^{-3}$ ), confirming nucleation events are a source of $\mathrm{N}$ not directly related to primary traffic emissions (Dall'Osto et al., 2013a; this special issue). A similar conclusion - although less clear - can be drawn if $\mathrm{BC}$ is used as an air quality parameter (Fig. 4c, d). The same applies to $\mathrm{CO}$ (although not shown). $\mathrm{PM}_{2.5}$ is regulated by the 2008/50/CE Directive. Figure 4e and $\mathrm{f}$ show that $\mathrm{RB}_{\text {clus_ } 1}$ and $\mathrm{RB}_{\text {clus } \_} 2$ clusters are the ones that recorded the highest $\mathrm{PM}_{2.5}$ levels and lower $\mathrm{N}$ concentrations in both cases. $\mathrm{UB}_{\text {clus_1 }}, \mathrm{T}_{\text {clus_1-3 }}$ and $\mathrm{NU}_{\text {clus }}$ show lower $\mathrm{PM}_{2.5}$ and higher $\mathrm{N}$ concentrations progressively, this trend being clearer for the total fraction $\mathrm{N}_{15-228 \mathrm{~nm}}$ (Fig. 4f). Figures $4 \mathrm{~g}$ and h show 
the corresponding graphs for $\mathrm{PM}_{\text {coarse }}$, the mass concentration of PM between 2.5 and $10 \mu \mathrm{m}$. Both figures clearly show three main groups: a first one enclosing the city monitoring sites $\left(\mathrm{UB}_{\text {site }}, \mathrm{RS}_{\text {site }}\right)$, a second one associated with the background hill urban site $\left(\mathrm{TC}_{\text {site }}\right)$ and a third one containing Background Pollution clusters. In both figures, the Traffic and Nucleation clusters associated with the city sites $\left(\mathrm{UB}_{\text {site }}, \mathrm{RS}_{\text {site }}\right)$ are located at the top right corner. When considering the same clusters but for $\mathrm{TC}_{\text {site, }}$, although they still show high $\mathrm{N}$, they contain less coarse particles than at the $\mathrm{RS}_{\text {site }}$ and $\mathrm{UB}_{\text {site, }}$, implying the city is a source of urban dust coarse aerosols not found in the background monitoring sites. This clearly suggests that the coarse dust detected in the city mostly arises from anthropogenic sources found in the city $\left(\mathrm{UB}_{\text {site }}, \mathrm{RS}_{\text {site }}\right)$ but not in the suburban areas $\left(\mathrm{TC}_{\text {site }}\right)$. Finally, in the bottom part of the graphs we find the Regional Background clusters. They show low values of $\mathrm{N}$ and moderate values of coarse particle mass.

\section{Conclusions}

Measurements of particle size distribution were made in the Barcelona urban area during the SAPUSS campaign (20 September-20 October 2010). Four SMPSs were simultaneously deployed at four different monitoring sites: a road site $\left(\mathrm{RS}_{\text {site }}\right)$, two urban background sites $\left(\mathrm{UB}_{\text {site }}\right.$ and $\left.\mathrm{TC}_{\text {site }}\right)$ and a regional background station $\left(\mathrm{RB}_{\text {site }}\right)$. Measurement size ranges for all monitoring sites were harmonised, resulting in a homogenous data set with particle sizes between 15 and $228 \mathrm{~nm}$ at $1 \mathrm{~h}$ resolution. A $k$-means clustering analysis was performed on the combined four data sets, resulting in nine size distributions that described aerosol population. Three clusters account for traffic conditions (30\%), three account for background pollution (54\%) and three described specific special cases $(16 \%)$. The traffic conditions influence the sites closest to their sources, while the more distant sites are more influenced by background clusters. Nucleation under high solar radiation conditions is a common feature in southern European cities and contributes to an increase in $\mathrm{N}$, although such particles often fail to grow to sizes above $10-15 \mathrm{~nm}$. This study also clearly shows that evaporation of traffic-related ultrafine aerosols occurs when the air mass moves away from the traffic hot spot. Particles of between 5 and $15 \mathrm{~nm}$ show the most complex behaviour. On the one hand, new non-traffic particles formed in cities often fail to grow above $15 \mathrm{~nm}$. On the other hand, 20-30 nm primary traffic particles shrink to smaller sizes soon after emission. Additional studies on the strategies to monitor in a comparable way $\mathrm{N}_{5-15 \mathrm{~nm}}$ levels, as well as on the origin and health effects of this specific size fraction, are therefore suggested in order to support decisions on the potential use of SMPS-CPC technologies for air quality monitoring, because this size range makes a major contribution to total particle numbers.
Supplementary material related to this article is available online at http://www.atmos-chem-phys.net/14/ 2973/2014/acp-14-2973-2014-supplement.pdf.

Acknowledgements. FP7-PEOPLE-2009-IEF, project number 254773, SAPUSS - Solving Aerosol Problems Using Synergistic Strategies (Marie Curie Actions - Intra European Fellowships. Manuel Dall'Osto). This study was previously supported by research projects from the D. G. de Calidad y Evaluación Ambiental (Spanish Ministry of the Environment) and the Spanish Ministry of Science and Innovation (CGL2010-19464 - VAMOS), and the Departament de Medi Ambient from the Generalitat de Catalunya and Diputació de Barcelona, which kindly supported data of gaseous pollutants. ACTRIS is also acknowledged for aerosol size distributions at the RB site. Meteorological data were provided by the Servei Meteorològic de Catalunya and by the Department of Physics from the University of Barcelona. Alfons Puertas (Secció de Meteorologia, Fabra observatory) is also acknowledged. The SAPUSS team is finally acknowledged.

Edited by: R. Vecchi

\section{References}

Amato, F., Pandolfi, M., Viana, M., Querol, X., Alastuey, A. and Moreno, T.: Spatial and chemical pattern of $\mathrm{PM}_{10}$ in road dust deposited in urban environment, Atmos. Environ., 43, 16501659, 2009.

Atkinson, R. W., Fuller, G. W., Anderson, H. R., Harrison, R. M. and Armstrong, B.: Urban particle metrics and health: A time series analysis, Epidemiology, 21, 501-511, 2010.

Beddows, D. C. S., Dall'Osto, M., and Harrison, R. M.: Cluster analysis of rural, urban and curbside atmospheric particle size data, Environ. Sci. Technol., 43, 4694-4700, 2009.

Birmili, W. and Wiedensohler, A.: New particle formation in the continental boundary leyer: Meteorological and gas phase parameter influence, Geophys. Res. Lett., 27, 20, 3325-3328, 2000.

Biswas, S., Fine, P. M., Geller, M. D., Hering, S. V., and Sioutas, C.: Performance evaluation of recently developed water- based condensation particle counter, Aerosol Sci. Tech., 39, 419-427, 2005.

Charron, A. and Harrison, R. M.: Primary particle formation from vehicle emissions during exhaust dilution in the roadside atmosphere, Atmos. Environ., 37, 4109-4119, 2003.

Cheung, H. C., Morawska, L., and Ristovski, Z. D.: Observation of new particle formation in subtropical urban environment, Atmos. Chem. Phys., 11, 3823-3833, doi:10.5194/acp-11-38232011, 2011.

Colbeck, I., Lazaridis, M.: Aerosol Science: Technology and Application. First Edition, John Wiley \& Sons, Ltd. ISBN:978-1-11997792-6, 2014.

Dall'Osto, M., Thorpe, A., Beddows, D. C. S., Harrison, R. M., Barlow, J. F., Dunbar, T., Williams, P. I., and Coe, H.: Remarkable dynamics of nanoparticles in the urban atmosphere, Atmos. Chem. Phys., 11, 6623-6637, doi:10.5194/acp-11-66232011, 2011a.

Dall'Osto, M., Monahan, C., Greaney, R., Beddows, D. C. S., Harrison, R. M., Ceburnis, D., and O'Dowd, C. D.: A statistical 
analysis of North East Atlantic (submicron) aerosol size distributions, Atmos. Chem. Phys., 11, 12567-12578, doi:10.5194/acp11-12567-2011, 2011b.

Dall'Osto, M., Beddows, D. C. S., Pey, J., Rodriguez, S., Alastuey, A., Harrison, R. M., and X. Querol: Urban aerosol size distributions over the Mediterranean city of Barcelona, NE Spain, Atmos. Chem. Phys., 12, 10693-10707, doi:10.5194/acp-1210693-2012, 2012.

Dall'Osto, M., Querol, X., Alastuey, A., O’Dowd, C., Harrison, R. M., Wenger, J., and Gómez Moreno, F. J.: On the spatial distribution and evolution of ultrafine particles in Barcelona, Atmos. Chem. Phys., 13, 741-759, doi:10.5194/acp-13-741-2013, 2013a.

Dall'Osto, M., Querol, X., Alastuey, A., Minguillon, M.C., Alier, M., Amato, F., Brines, M., Cusak, M., Grimalt, J. O., Karanasiou, A., Moreno, T., Pandolfi, M., Pey, J., Reche, C., Ripoll, A., Tauler, R., Van Drooge, B. L., Viana, M., Harrison, R.M., Gietl, J., Beddows, D., Bloss, W., O'Dowd,C., Ceburnis, D., Martucci, G., Ng, S., Worsnop, D., Wenger, J., Mc Gillcuddy, E., Sudou, J., Healy, R., Lucarelli, F., Nava, S., Jimenez, J.L., Gomez-Moreno, F., Artiñano, B., Prevot, A.S.H. Pfaffenberger,L., Frey, S., Wilsenack, F., Casabona, D., Jiménez-Guerrero, D., Gross, D., and Cots, N.: Presenting SAPUSS: solving aerosol problem by using synergistic strategies at Barcelona, Spain, Atmos. Chem. Phys., 13, 8991-9019, doi:10.5194/acp-13-8991-2013,2013b.

Davidson, C., Phalen, R., and Salomon, P.: Airborne particulate matter and human health: a review, Aerosol Sci. Technol., 39, 737-749, 2005.

Fujitani, Y., Kumar, P., Tamura, K, fushimi, A., Hasegawa, S., Takahasi, K., Tanabe, K., Kobayashi, S., and Hirano, S.: Seasonal differences of the atmospheric particle size distribution in a metropolitan area in Japan, Sci. Total Environ., 437, 339-347, 2012.

Harrison, R. M. and Yin, J.: Particulate matter in the atmosphere: which particle properties are important for its effects on health?, Sci. Total. Environ., 249, 85-101, 2000.

Harrison, R. M., Beddows, D. C. S., and Dall'Osto, M.: PMF analysis of wide-range particle size spectra collected on a major highway, Environ. Sci. Technol., 45, 5522-5528, 2011.

Harrison, R. M., Dall'Osto, M., Beddows, D. C. S., Thorpe, A. J., Bloss, W. J., Allan, J. D., Coe, H., Dorsey, J. R., Gallagher, M., Martin, C., Whitehead, J., Williams, P. I., Jones, R. L., Langridge, J. M., Benton, A. K., Ball, S. M., Langford, B., Hewitt, C. N., Davison, B., Martin, D., Petersson, K. F., Henshaw, S. J., White, I. R., Shallcross, D. E., Barlow, J. F., Dunbar, T., Davies, F., Nemitz, E., Phillips, G. J., Helfter, C., Di Marco, C. F., and Smith, S.: Atmospheric chemistry and physics in the atmosphere of a developed megacity (London): an overview of the REPARTEE experiment and its conclusions, Atmos. Chem. Phys., 12, 3065-3114, doi:10.5194/acp-12-3065-2012, 2012.

Hussein, T., Puustinen, A., Aalto, P. P., Mäkelä, J. M., Hämeri, K., and Kulmala, M.: Urban aerosol number size distributions, Atmos. Chem. Phys., 4, 391-411, doi:10.5194/acp-4-391-2004, 2004.

Hussein, T., Karppinen, A., Kukkonen, J., Härkönen, J., Aalto, P. P., Hämeri, K., Kerminen, V. M., and Kulmala, M.: Meteorlogical dependence of size fractioned number concentration of urban aerosol particles, Atmos. Environ., 40, 1427-1440, 2006.
Hudda, N., Cheung, K., Moore, K. F., and Sioutas, C.: Intercommunity variability in total particle number concentrations in the eastern Los Angeles air basin, Atmos. Chem. Phys., 10, 11385-11399, doi:10.5194/acp-10-11385-2010, 2010.

IPCC: Intergovernmental Panel on Climate Change. Report, Cambridge Univ Press, Cambridge, UK, available at: http://www. ipcc.ch/ipccreports/ar4-wg1.htm (last access: March 2013), 2007.

Kumar, P., Ketzel, M., Vardoulakis, S., Pirjola, L., and Britter, R.: Dynamics and dispersion modelling of nanoparticles from road traffic in the urban atmsopheric environment: a review, J. Aerosol Sci., 42, 580-603, 2011.

Li, T., Chen, X., and Yan, Z.: Comparison of fine particles emissions of light-duty gasolina vehicles from chassis dynamometer tests and on-road measurements, Atmos. Environ., 68, 82-91, 2013.

Millán, M., Mantilla, E., Salvador, S., Carratalá, A., Sanz, M. J., Alonso, L., Gangoti, G., and Navazo, M.: Ozone cylces in the Western Mediterranean Basin: Interpretation of monitoring data in complex coastal terrain, J. Appl. Meteorol., 39, 487-508, 2000.

Ntziachristos, L., Ning, Z., Geller, M. D., and Sioutas, C.: Particle concentration and characteristics near a major freeway with heavy-duty diesel traffic, Environ. Sci. Technol., 41, 2223-2230, 2007.

Olivares, G., Johansson, C., Ström, J. and Hansson, H. C.: The role of ambient temperature for particle number concentrations in a street canyon, Atmos. Environ., 41, 2145-2155, 2007.

Pey, J., Rodríguez, S., Querol, X., Alastuey, A., Moreno, T., Putaud, J. P., and Van Dingenen, R.: Variations of urban aerosols in the western Mediterranean, Atmos. Environ., 42, 9052-9062, 2008.

Pey, J., Querol, X., Alastuey, A., Rodríguez, S., Putaud, J. P., and Van Dingenen, R.: Source Apportionment of urban fine and ultrafine particle number concentration in a Western Mediterranean city, Atmos. Environ., 43, 4407-4415, 2009.

Reche, C., Querol, X., Alastuey, A., Viana, M., Pey, J., Moreno, T., Rodríguez, S., González, Y., Fernández-Camacho, R., de la Rosa, J., Dall'Osto, M., Prévôt, A. S. H., Hueglin, C., Harrison, R. M., and Quincey, P.: New considerations for PM, Black Carbon and particle number concentration for air quality monitoring across different European cities, Atmos. Chem. Phys., 11, 6207-6227, doi:10.5194/acp-11-6207-2011, 2011.

Rönkkö, T., Virtanen, A., Kannosto, J., Keskinen, J., Lappi, M., and Pirjola, L.: Nucleation mode particles with a nonvolatile core in the exhaust of a heavy duty diesel vehicle, Environ. Sci. Technol., 41, 6384-6389, 2007.

Seaton, A., Godden, D., MacNee, W., and Donaldson, K.: Particulate air pollution and acute health effects, Lancet, 345, 176-178, 1995.

Shi, J. P., Mark, D., and Harrison, R. M.: Characterization of particles from a current technology heavy-duty diesel engine, Environ. Sci. Technol., 34, 748-755, 2000.

Swietlicki, E., Hansson, H.-C., Hämeri, K., Svenningsson, B., Massling, A., McFinnigans, G., McMurray, P. H., Petäjä, T., Tunved, P., Gysel, M., Topping, D., Weingartner, E., Baltensperger, U., Rissler, J., Wiedensohler, A., and Kulmala, M.: Hygroscopic properties of submicrometer atmospheric aerosol particles measured with H-TDMA instruments in various environments-a review, Tellus, 60B, 432-469, 2008. 